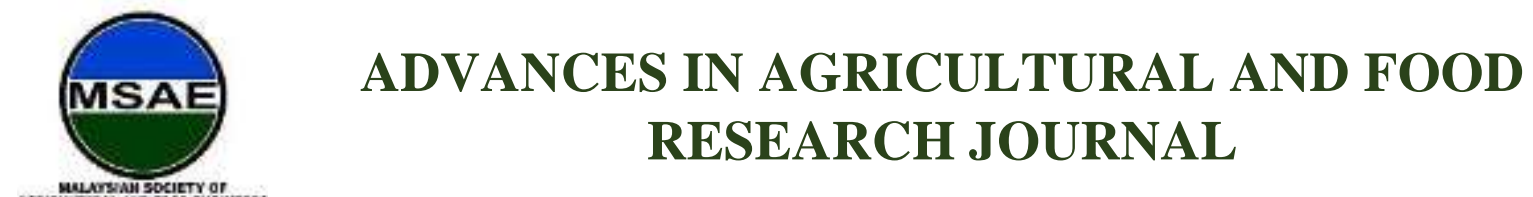

HHPUBLISHER

Short Communication

\title{
Evaluation of Planting Spacing and Effects on the Yield for Malaysia Grain Corn Production
}

Mohd Khusairy Khadzir ${ }^{1}$, Erwan Shah Shari ${ }^{1}$, Mohd Haniff Ahmad ${ }^{1}$, Rohazrin Abdul Rani ${ }^{2}$, Adli Fikri Ahmad Sayuti $^{2}$ ${ }^{1}$ Pusat Penyelidikan Kejuruteraan, MARDI Seberang Perai, Kepala Batas, 13200 Pulau Pinang, Malaysia,
mkhusairy@mardi.gov.my, erwanshah@mardi.gov.my, mhaniff@ mardi.gov.my

${ }^{2}$ Pusat Penyelidikan Kejuruteraan, MARDI Ibu Pejabat Persiaran MARDI-UPM,43400 Serdang, Malaysia, rohazrin@mardi.gov.my, Adli@mardi.gov.my

*Corresponding author: Mohd Khusairy Khadzir, Pusat Penyelidikan Kejuruteraan, MARDI Seberang Perai, Kepala Batas, 13200 Pulau Pinang, Malaysia; mkhusairy@mardi.gov.my

Abstract: Currently, the average grain corn yield in farmer fields is 3-4t/ha and sometimes as low as 1 to $2 \mathrm{t} / \mathrm{ha}$. Whereas large scale planting in the research station, the harvested average yield can reach up to 5 to $6 \mathrm{t} / \mathrm{ha}$ and CCT yield of $8-9 \mathrm{t} / \mathrm{ha}$, and the operation cost is more than RM 5,000.00/ha. The planting spacing study is one of the mechanisms for lowering the cost of grain corn cultivation. It also plays a vital role in the growth of corn crops. This study aims to evaluate the effects of planting spacing on the yield of grain corn. The evaluation has been conducted at MARDI Seberang Perai, Pulau Pinang. A 90hp tractor is attached with a pneumatic row planting machine used for the cultivation operation. Five planting spacing $(13,16,19,22$, and $25 \mathrm{~cm})$ were evaluated. The study showed no significant differences in growth performance and cob corn. For the yield, the results showed significant differences at $p<0.05$. The highest yield at planting spacing at $13 \mathrm{~cm}$ is $10.78 \mathrm{tan} / \mathrm{ha}$.

Keywords: planting spacing; grouser; reduce cost; cultivation; CCT

Received: $26^{\text {th }}$ February 2021

Received in revised form: $24^{\text {th }}$ May 2021

Citation: Khadzie, M. K., Shari, E. S., Ahmad, M. H., et al. (2021). Evaluation of planting spacing and effects on the yield for Malaysia grain corn

Accepted: $30^{\text {th }}$ May 2021 production. Adv Agri Food Res J 2021; 2(1)

Available Online: $15^{\text {th }}$ June 2021 a0000211. https://doi.org/10.36877/aafrj.a0000211

\section{Introduction}

Grain corn is an essential agricultural commodity in the livestock feed industry country. Asean Food Security Information System (AFSIS) reported that each year, the country imports 3.71 million tons of grain corn worth RM 3.09 billion from the international market and accounted for $14 \%$ of the imports of agricultural materials. In addition, grain corn is the main composition in animal feed, especially in the country's poultry industry which has contributed an average value-added of RM 10 billion in the last five years since 2015 . 
Therefore, developing the grain corn industry is very important to ensure the poultry industry's stability and reduce national imports. Therefore, the government has taken the initiative to develop the national grain corn industry by formulating livelihoods by making grain corn commodities among the commodities chosen for cultivation in this country. In line with the government's efforts to develop new livelihood sources nationally and refer to Pelan Tindakan Jagung Bijian Negara (MOA 2018), MARDI has taken the initiative to support this aspiration by implementing the Project Grain Corn Research since 2016.

Mechanization plays a vital role in ensuring survival and improving grain corn productivity, especially for large-scale plantations. Mechanization makes plantation operations more efficient with reduce operation time and less labour use. The objective of the experiment was to investigate the influence of planting spacing on crop growth, yield components, and grain yield in Malaysia using mechanize planting machine. For each $1 \mathrm{~cm}$ decrease in the standard deviation, Doerge and Hall (2002) reported yield increases of 101 $\mathrm{kg} \mathrm{ha}^{-1}$. On the other hand, Johnson and Mulvaney (1980) have reported a decline in yield due to increased distance length in a uniformly spaced stand. Therefore, the research was conducted to investigate the effect of intra-row spacing on the components of crop performance and grain corn yield.

\section{Materials and Methods}

Field tests were conducted at MARDI Seberang Perai, Pulau Pinang in two seasons, off-season in April 2019 and the main season in October 2019. As a result, seed seeding and basic fertilizer applications are carried out simultaneously in one operation. This operation is carried out using a pneumatic row seeder (Gaspardo type a tractor attachment with four rows of seed nursery tools with a donor tool steel (Figure 1).

Before planting, seed rate drop was determined to get the rate recommended for cultivation. There is a schedule of recommendation adjustments from manufacturers that can be found on the machine, but further verification is necessary to adjust the machine with varying local conditions. Planting distance can be calibrated by taking the number of seeds that fall from a single travel distance. For example, if a planting distance of $20 \mathrm{~cm}$ is required, about 50-52 seeds should be planted in a $10 \mathrm{~m}$ length row, equivalent to Equation 1.

$$
\text { Travel distance }(\mathrm{cm})=\frac{\text { Planting distance }(\mathrm{cm})}{\text { The number of seeds falls }}
$$

For the planting distance study, the planting spacing was $75 \mathrm{~cm}$ between rows with $13 \mathrm{~cm}, 16 \mathrm{~cm}, 19 \mathrm{~cm}, 22 \mathrm{~cm}$, and $25 \mathrm{~cm}$ distance along the row was used, with a seed nursery rate in the range of $18-20 \mathrm{~kg} / \mathrm{ha}$. The grain corn variety $\mathrm{P} 4546$ was used in this experiment. The experiment was arranged in five planting spacing at 13, 16, 19, 22, and $25 \mathrm{~cm}$, which was laid out in the Randomized Complete Block Design (RCBD). Theoretically, when implementing these planting distances, the plant density at each distance is 106666, 93333, 
73333, 60000, and 53333, respectively. Data on plant height, growth performance, and yield components were also collected. Crop distance adjustments were made by changing the sprocket system on the MASCHIO GASPARDO planter that matches the adopted nursery plate. In order to change the planting distance on the planter system, the chain in the planter gearbox was pushed loosen and then positioned on the located gears by reference to the manufacturer's table on corn grain corn disc plate no. 26 (Figure 2). The chain was twisted again with the lever (Figure 1), and the cover was closed. The seed planting distance is obtained with the pinions (wheel $\mathrm{C}-\mathrm{D}$ ) mounted on the planting unit (Figure 2)

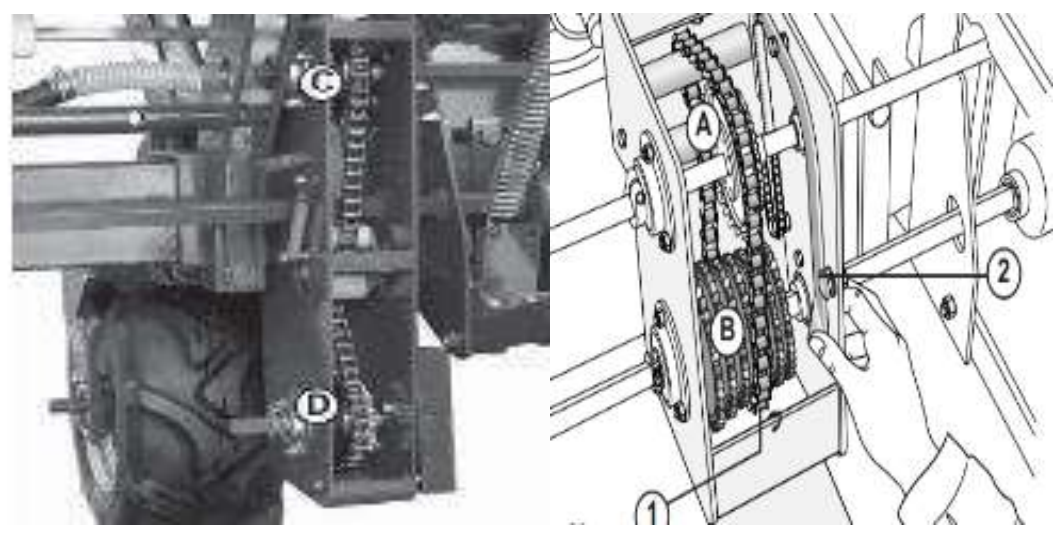

Figure 1. Planter gearboxes

\begin{tabular}{ccc}
\hline Wheel & $\begin{array}{c}\text { Gear Box } \\
\text { Combination }\end{array}$ & $\begin{array}{c}\text { Planting } \\
\text { distance }\end{array}$ \\
C-D & A-B & (cm) \\
\hline $16-23$ & $16-20$ & 13.0 \\
$23-23$ & $16-17$ & 16.0 \\
$23-23$ & $16-20$ & 19.0 \\
$23-23$ & $16-23$ & 22.0 \\
$23-16$ & $16-19$ & 25.0 \\
\hline
\end{tabular}




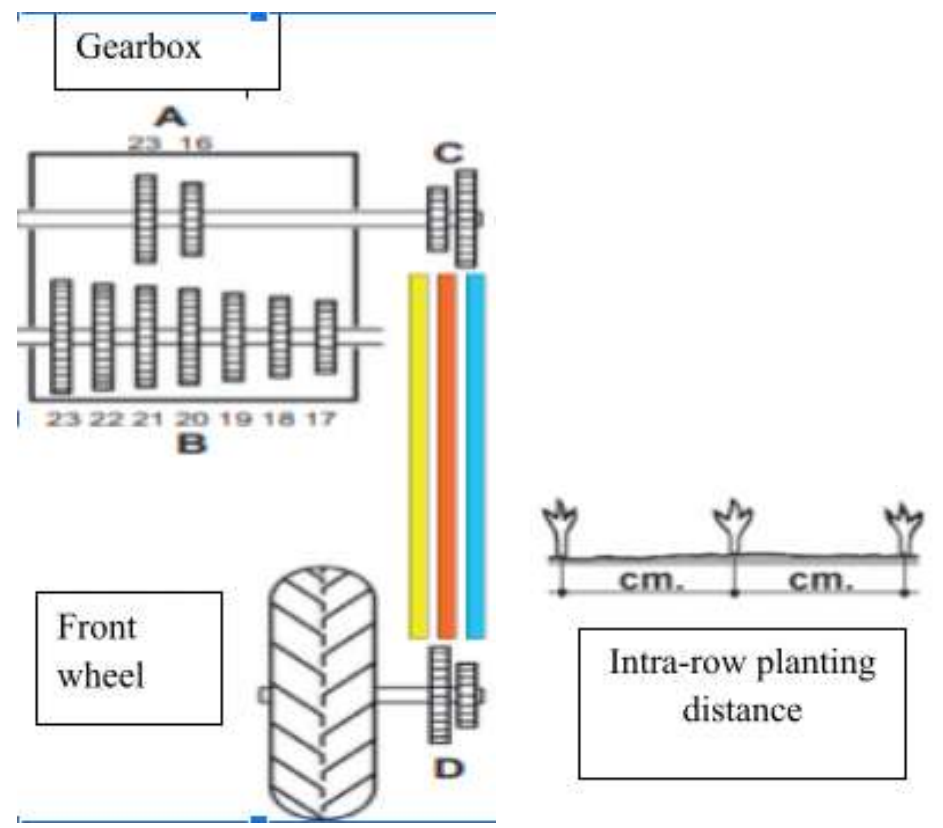

Figure 2. Gearbox positioning for planting distance using seed disc plate no. 26 for grain corn (referring manufacturer table from MASCHIO GASPARDO manual book)

Grain corn seed is planted at a 3-5 $\mathrm{cm}$ depth for the sandy loam soil type in MARDI Seberang Perai. Thus, the seeds planted shallower in relatively shallow soil weight in areas with high clay content compared to with something as light as sandy soil. The depth of the seed nursery is controlled by adjusting the press wheel located on the back of the machine, as shown in Figure 3.

Tractor speed during planting operation is $4-5 \mathrm{~km} / \mathrm{h}$, which gives a work rate of 1.5 $\mathrm{ha} / \mathrm{h}$. However, in a poor work environment, the work rate was as low as $1.2 \mathrm{ha} / \mathrm{h}$. It is found that high speeds can cause improper planting distance, and there will be more points lost. Manual replanting was done seven days after planting to fill the space where the seeds do not germinate or where the machine does not drop the seeds during planting. 


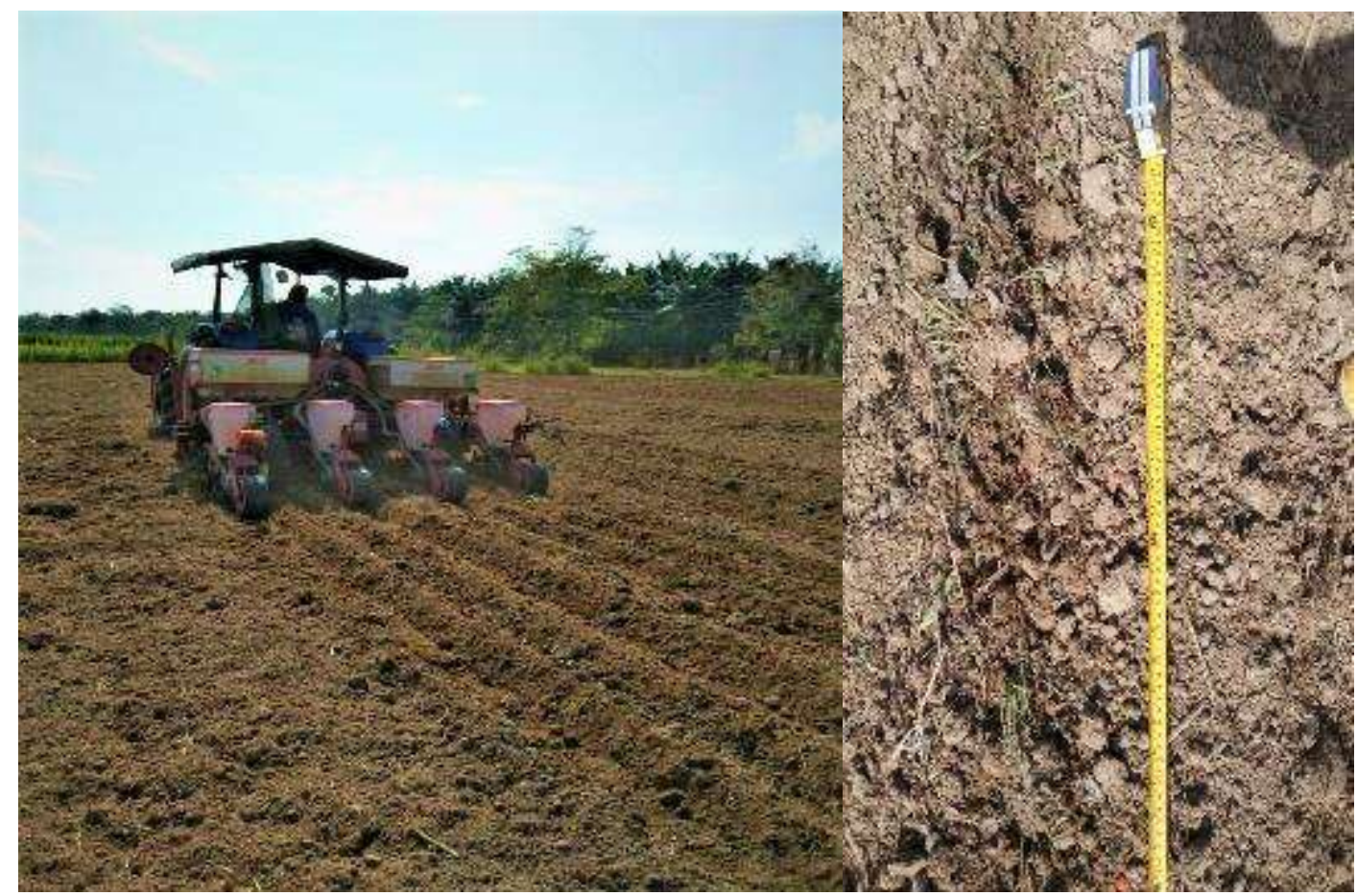

(a)

(b)

Figure 3. (a) Cultivation of grain corn using planting machines; (b) Measuring grain corn planting distance.

The fertilizer used is NPK 15:15:15 (Green) compound fertilizer, at the rate of 400 $\mathrm{kg} / \mathrm{ha}$. Same as seed nurseries, fertilizer tools are also pre-calibrated to obtain the exact amount of fertilizer as determined before planting is carried out. The experimental data were compared with the SAS software with Duncan multiple range test. The difference was statistically significant at $p<0.05$.

\section{Results}

\subsection{Plant Height}

This experiment aims to investigate the influence of planting spacing on grain corn growth performance and yield components. The study results found that the relationship of plant height increased until 60 days after planting (Figure 4). At a planting distance, $19 \mathrm{~cm}$ shows the highest plant height $(200 \mathrm{~cm}) 60$ days after planting. There is no increase in plant height up to 105 days after planting for all planting spacing. 


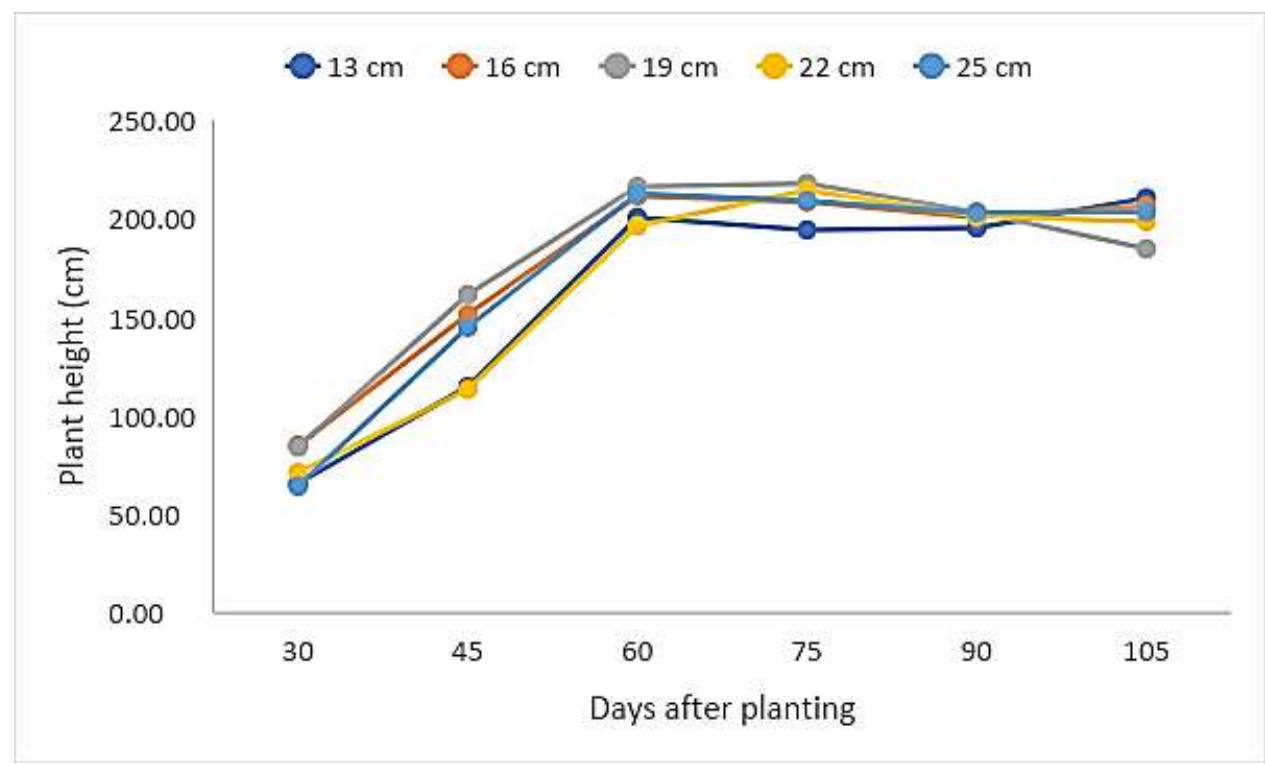

Figure 4. Relationship between planting distance to cob diameter and plant height

\subsection{Fresh Weight of Plant}

The effect of planting spacing showed the same relationship with other treatments. After 30 days of planting, there is an increase in fresh weight until 60 days after planting. The fresh weight for planting distance at $25 \mathrm{~cm}$ shows the highest at 90 days after planting compare to others (Figure 5). Most of the treatment showed decreasing the fresh weight of the plant as the number of days increase.

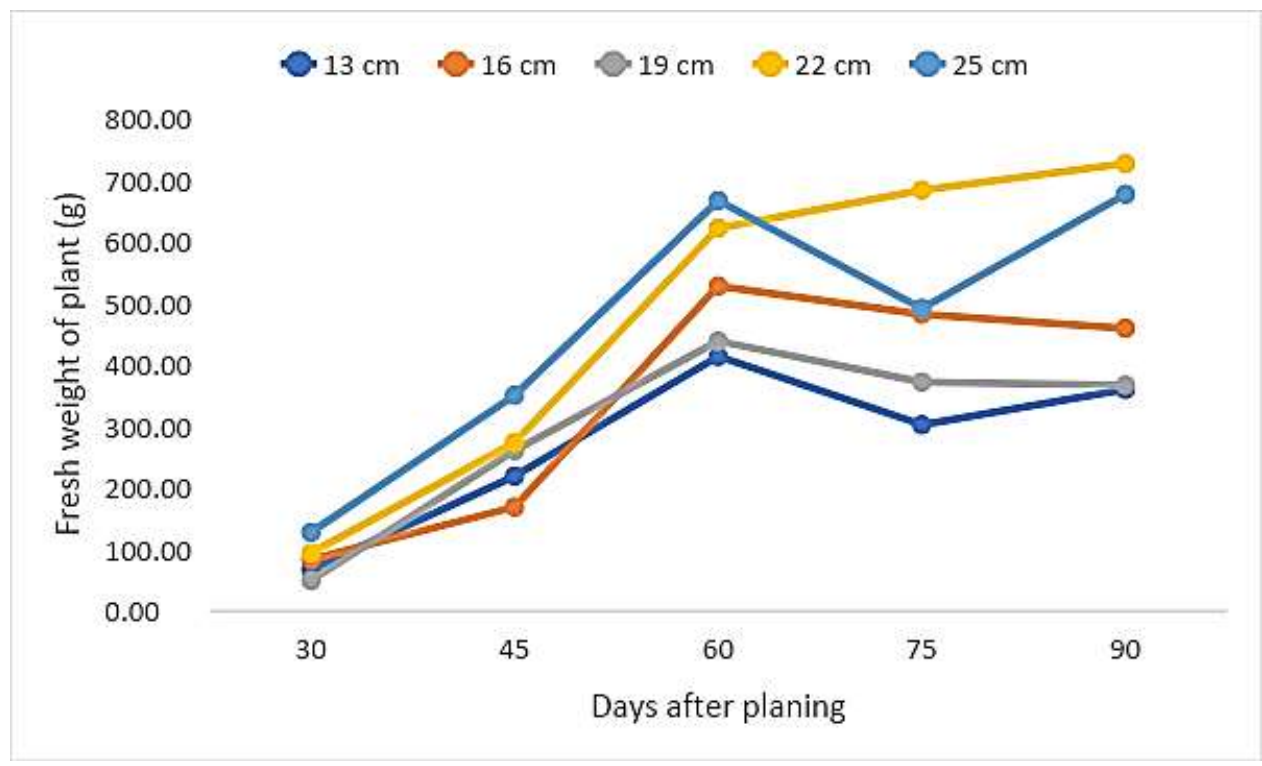

Figure 5. Relationship between days after planting and fresh weight of plant ( $\mathrm{g}$ ) 


\subsection{Cob Length and Diameter}

Figure 6 shows the difference in cob size for each crop distance studied. There were no significant differences among the cob length and diameter of the yield component. The maximum cob diameter was recorded at planting spacing $19 \mathrm{~cm}$ and $22 \mathrm{~cm}$. Thus, there is a slight variation in the shape of the corn cob in each crop distance. However, it is not significant among others (Figure 7).

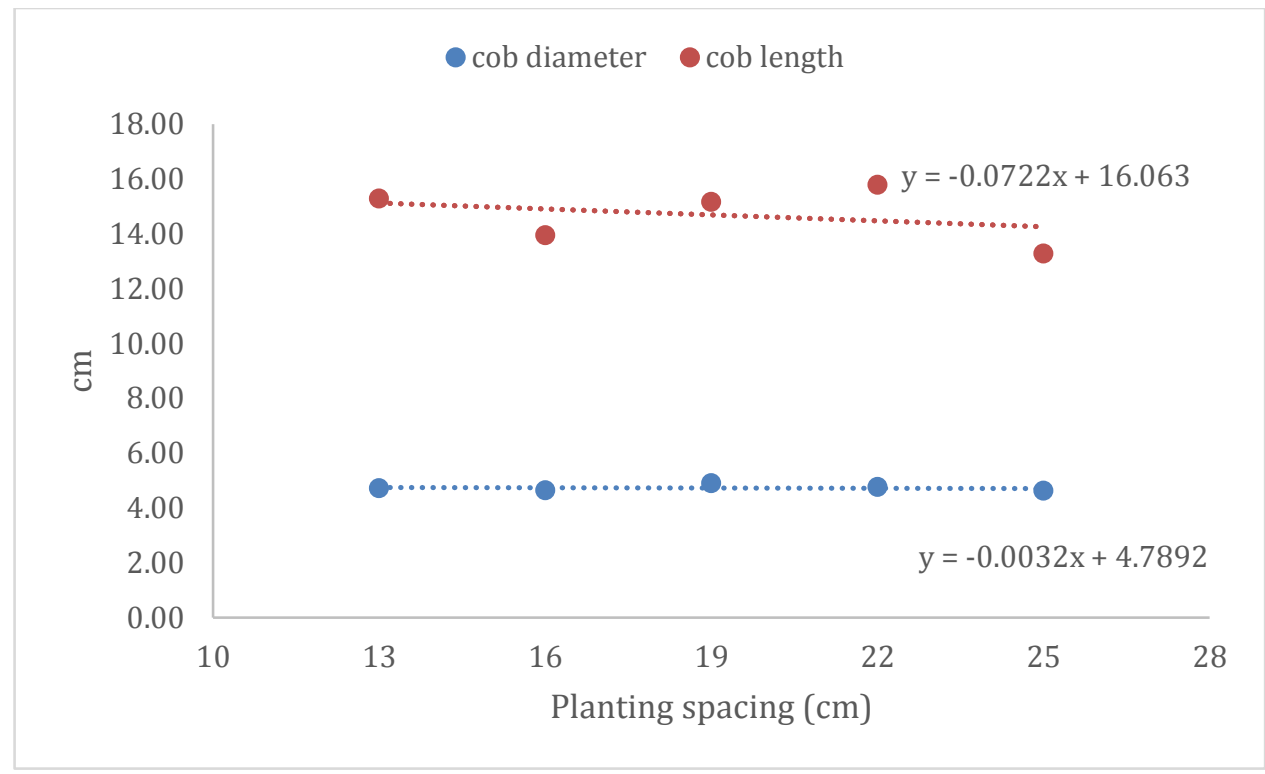

Figure 6. Relationship between planting spacing to cob diameter and cob length

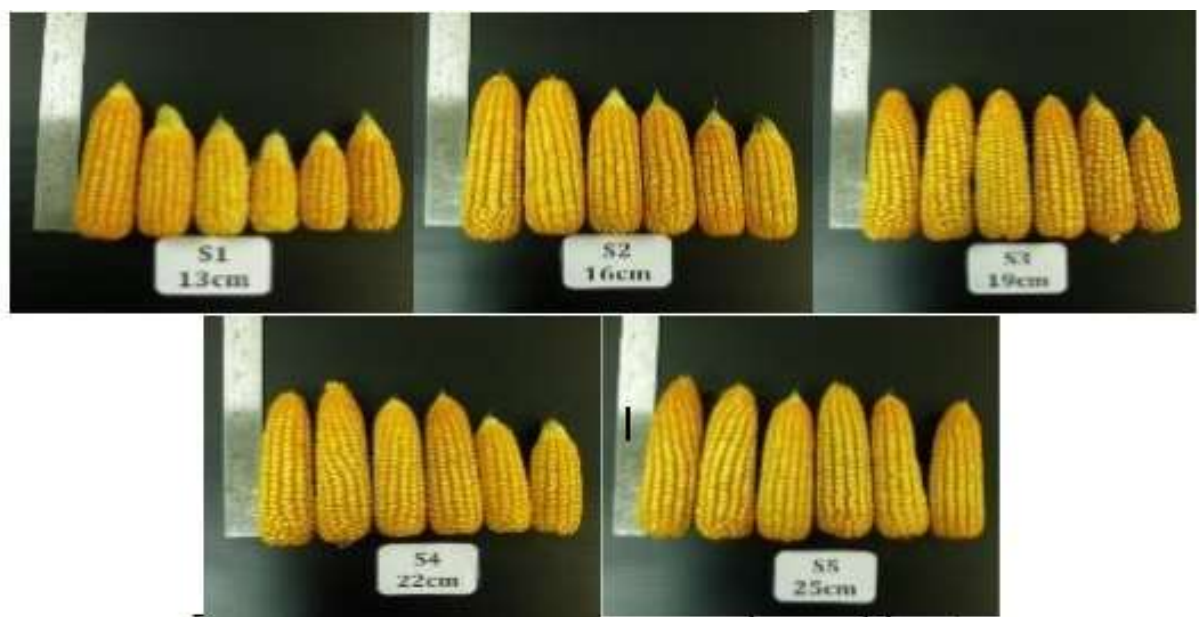

Figure 7. The effect of planting spacing on cob size and diameter

\subsection{Grain Yield}

The interaction effect of intra-row spacing on grain yield per hectare was significant. CT (Crop Cutting Test) grain yields were recorded from 13, 19, 16, 22, and $25 \mathrm{~cm}$. The results showed significant differences $(p<0.05)$ for corn yield. The highest CCT yield of corn was at a planting distance of $13 \mathrm{~cm}$ and $19 \mathrm{~cm}$ accordingly (Figure 8 ). 


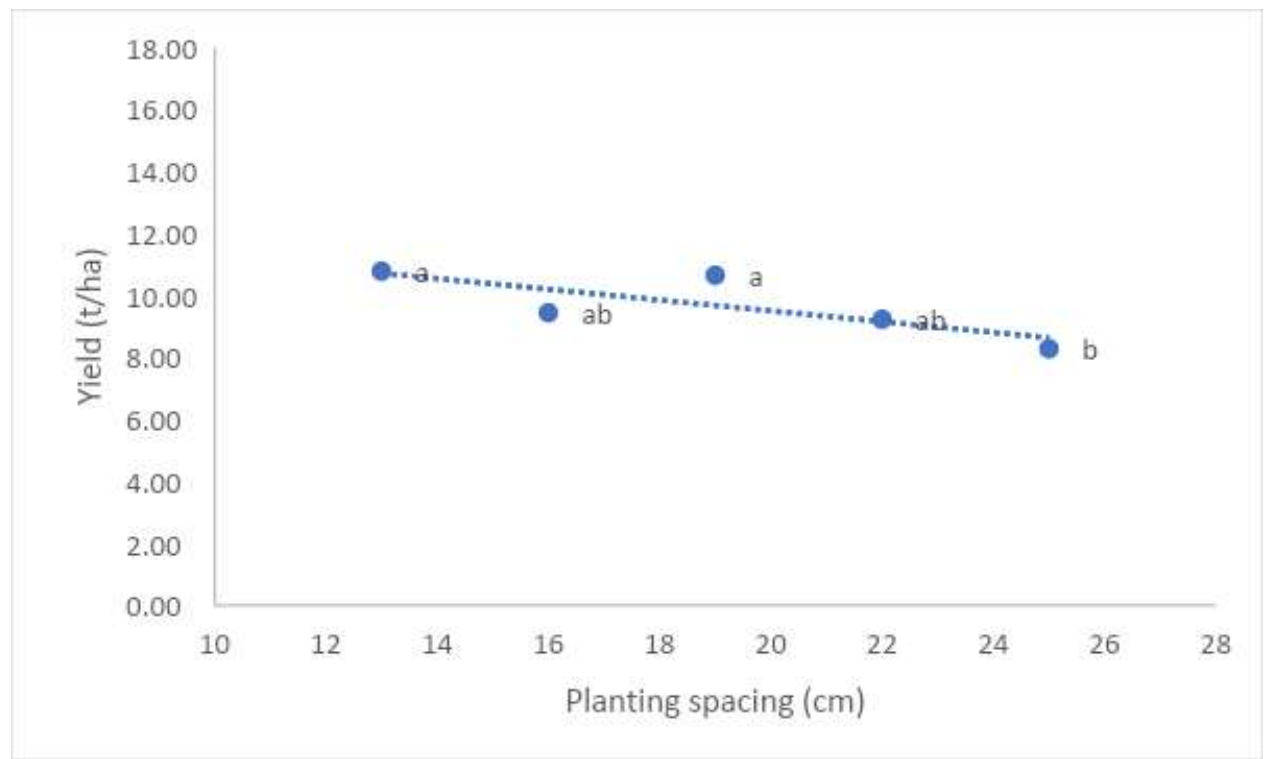

Figure 8. Relationship between planting spacing to yield performance (t/ha). The same letter is not significantly different based on Duncan 95\% confidence intervals

\section{Conclusions}

In summary, the outcome of this study showed that corn production at a relatively narrow spacing $(13 \mathrm{~cm})$ or intermediate spacing $(19 \mathrm{~cm})$ would increase the yield of grain corn. Furthermore, this experiment showed that the $13 \mathrm{~cm}$ and $19 \mathrm{~cm}$ intra row spacing was significantly higher than the others for the yield components.

It can also be concluded from this observation that the planting of grain corn at $13 \mathrm{~cm}$ and $19 \mathrm{~cm}$ per row is suggested for grain yield. Planting spacing at $19 \mathrm{~cm}$ was the most acceptable since it needs fewer seeds, but the exact yield is $13 \mathrm{~cm}$. However, this preliminary analysis is based on two seasons in a single place and uses one variation. Therefore, further studies on various varieties are required at different seasons and locations for further investigation and a thorough recommendation. The highest CCT yield of corn at a planting distance of $13 \mathrm{~cm}$ is $10.78 \mathrm{t} / \mathrm{ha}$, followed by $19 \mathrm{~cm}, 10.65 \mathrm{t} / \mathrm{ha}$. There is no significant difference between the planting distance of $13 \mathrm{~cm}$ and $19 \mathrm{~cm}$ for yield performance. In this study, seed and fertilizer input cost as compared to traditional planting distances of $20 \mathrm{~cm}$. Therefore, it was determined that $19 \mathrm{~cm}$ is the most acceptable planting distance for grain corn planting.

Conflicts of Interest: The authors declare no conflict of interest.

\section{References}

AFIS (2016). ASEAN Agricultural Commodity Outlook Report No. 14 June 2015. Asean Food Security Information System (AFSIS). Office of Agricultural Eco nomics (OAE)

Doerge, T. \& Hall, T. (2002). 2002 Wisconsin Fertilizer, Aglime and Pest Management Conference. Madison, WI. On-farm evaluation of with-in row plant spacing uniformity. 
Eskandarnejada, S., S. Khorasani, S. Bakhtiaric, et al. (2013). Effect of row spacing and plant density on yield and yield components of sweet corn (Zea mays L.). Journal of Crop Science, l3(1): 81-88.

Johnson, R. R \& Mulvaney, D. L. (1980). Development of a model for use in maize replant decisions. Agronomy Journal, 72: 459-464.

M.Sárvári \& P. Pepó, (2014). Effect of Production Factors on Maize Yield and Yield Stability. Cereal Research Communications, 42(4) 710-720.

Mohd Khusairy, K., Rohazrin, A. R. \& Adli Fikri, A. S. (2019). Penyediaan kawasan untuk penanaman. Laporan Khas Potensi Penanaman Jagung Di Malaysia: Pengalaman MARDI. ISBN 978-967-936672-3.

Rohazrin, A.R., Adli Fikri, A.S., \& Mohd Khusairy, K. (2019). Mekanisasi pengeluaran jagung bijian. Laporan Khas Potensi Penanaman Jagung Di Malaysia: Pengalaman MARDI. ISBN 978-967-936-672-3.

SAS (Statistical Analysis) Institute. (2004). SAS user guides version 9.1. SAS Inc. Cary. North Carolina, USA.

Yousaf, N., A. Raouf, M.S., S. Kamel S. Amer. (2007). Investigating the influence of varying row spacing and planting density on growth characteristics, agronomic and yield traits, quality of grain and nutrient uptake patterns of diverse maize (Zea mays L.) hybrids. Journal of Agriculture and Biology, 8, $120-123$.

Copyright (C) 2021 by Khadzir M. K. et al. and HH Publisher. This work is licensed under the Creative

Commons Attribution-NonCommercial 4.0 International Lisence (CC-BY-NC4.0) 